\title{
Characteristics of Urban Agglomerations in Different Continents: History, Patterns, Dynamics, Drivers and Trends
}

\author{
Wolfgang Loibl, Ghazal Etminan, \\ Ernst Gebetsroither-Geringer, \\ Hans-Martin Neumann and \\ Santiago Sanchez-Guzman \\ Additional information is available at the end of the chapter
}

http://dx.doi.org/10.5772/intechopen.73524

\begin{abstract}
Urban agglomerations show different development patterns and stages. Here, we describe, discuss and compare urban agglomerations in different continents. The introduction section gives a general overview of specific issues of urban agglomerations. Different characteristics in Europe, Asia and America are discussed as experienced by the article's co-authors, living in or working for urban agglomerations in these continents. First, the history of urbanization and agglomeration evolvement is described, then patterns, functional structures and relations, drivers as well as social and demographic characteristics are discussed (e.g. migration, aging, household structure, housing patterns, workplaces, etc.). Transportation infrastructure (roads, public transport systems) is also addressed as trigger for spatial dynamics causing certain effects (floor space, office and apartment rents releasing urban sprawl or hyper-densification), as well as gentrification. Further topics are urban governance and its impact on agglomeration development. Recent state and future trends will be debated, if important. A conclusion section summarizes the comparison of state, dynamics, drivers and trends.
\end{abstract}

Keywords: urban agglomeration, trends, drivers, patterns, functions and relations 


\section{Introduction}

Urban agglomerations can be defined as contiguously built-up area, shaped by one core city or by several adjacent cities, sharing industry-, infrastructure- and housing-land use with highdensity levels as well as embedded open spaces. Urban agglomerations can be addressed in different ways ranging from "large cities," "urban economic zones," to "integrated groups of cities that share a common interest and fate," Fang and Yu [1] gave a comprehensive overview on the different contexts. Urban agglomeration is a somehow technical term emphasizing extent and morphology. We prefer the term "metropolitan region," which better labels sociospatial systems addressing activity and interest sharing of urban actors as well as the drivers, dynamics and functions which result in certain pattern and shape.

\subsection{General triggers extending urban agglomerations}

The utmost driving force of urban agglomerations is growth! The major reason for growth is population migration towards cities and metropolitan regions, driven by the population expectation, to find attractive living conditions (c. f. [2, 3]). Urban population growth and related housing demand are mostly caused by migration of rural population from rural areas or from remote (emerging) countries. There exist various migration theories. Bogue [4] addresses push

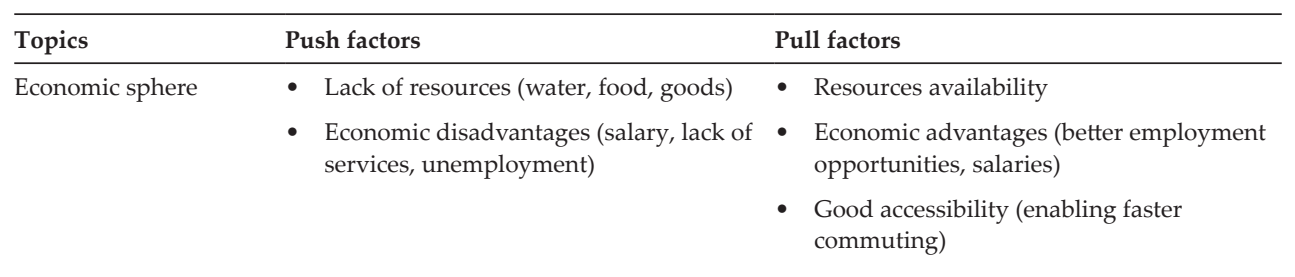

Housing/living condition sphere

Social sphere
Dissatisfaction with present living conditions:

- Lack of housing

- Low neighbourhood quality

- Few social, educational, leisure opportunities

- End of professional education

- Change of job, increase of personal income

- Family status change (marriage, children...)
Pleasant neighbourhood and surroundings

- Sufficient housing, building land provision

- Better neighbourhood quality

- Good social, education, leisure facilities

- Appropriate social neighbourhood structure

- Former neighbours and friends moved earlier to the target area, which evolves as homogenous ethnic district

- Building homogenous ethnic districts "Ghettos"

Source: Adapted from Refs. [3, 4].

Table 1. General driving forces of urban migration. 
and pull factors triggering migration decisions. In Table 1, these factors have been distinguished into three spheres.

Important push and pull factors for urban migration refer to the economic and the housing/ living condition sphere. The social sphere is only considered if the other two spheres are fulfilled. Social sphere-related desires vary much with respect to personal needs.

\subsection{History and dynamics: patterns and triggers shaping growth}

\subsubsection{Economy and employment}

Economically driven expectations of newcomers are triggered by the economic attractiveness of the agglomeration (c. f. [5]). Larger agglomerations - in developed as well as in emerging countries - show higher chances appealing more customers to gain income, higher salary or profit.

The economic sector depends on location factors. High quality services and administrations allow occupying the central core of a metropolitan region resulting in very high rents. The demand for office space in central areas triggers density increase in the central business districts (CBDs) within urban agglomerations. Agglomeration advantages attract businesses of different size, especially globally acting, powerful companies, establishing new offices to benefit from contact opportunities, good traffic connections, the large number of potential employees and clients. These agglomeration economies of scale are result of spatial proximity and frequency of opportunities, which are major contributing factors to the growth of cities [6]. Benefits arise from:

- low transportation costs

- big (local) markets

- large supply with labour and reducing search costs

- accumulation of knowledge and knowledge spillovers between companies [7].

Hiring specialized staff is easier in large agglomerations. More people undertake professional training and education, and the number of highly skilled employees is larger, since new academic personnel leave the city's universities and more already skilled personnel work in competing companies nearby, which may change the workplace for higher salary [8].

While the highly specialized service sector (banking, insurance, ICT, R\&D, governmental and urban administration) has its allocation focus in the centres, increasing densification, space intensive enterprises (logistics, retail- and large production sites), relocate to cheaper areas outside the urban cores, thus contributing to urban sprawl.

\subsubsection{Housing}

Despite high pressure on building land and rents, in-migration of new population to the cities is a steadily observed trend. Migration patterns in developed countries depend on the wealth of the potential movers able to rent or buy an apartment, where wealthy people are gradually displacing less wealthy ones, forcing them to move to cheaper outskirt areas, living often in 
low quality social housing blocks. Furthermore, central areas evolve as attractive neighbourhoods for the wealthy with short distance food supply, leisure opportunities, education facilities and social care.

Housing development in emerging countries shows extreme patterns. Displacement of poor people triggers informal housing in many ways.

\subsubsection{Urban sprawl versus "leapfrogging" urban development}

Urban sprawl "flooding" opens spaces around single core cities or between several cities and is the major dynamic to build urban agglomerations. Urban sprawl and its reasons have been discussed by many authors (e.g. by Bhatta [9] who provided a table of 30 reasons). In the nineteenth century during industrialization, the cities' density increased and living conditions declined because of coal fire use, leading to heavy air pollution in the cities and their industrial belts. Expansion of urban regions was driven in Europe during this century by new railway lines resulting in a "leapfrogging" urban development: With growing economic prosperity and expanding railway networks, the middle class move towards the suburban towns with better quality of life, while working in the cities, evolving commuting patterns along the railway lines. In London, this trend started around 1850, in Paris in 1890 and in New York City in early 1900 [10].

This urbanization trend was initiated during the 19th century by railway lines and train stations. In the 20th century, it was transformed to uncontrolled urban sprawl, which was triggered by private cars, allowing to settle in open land near already built-up areas, which provides easy access to the core city as well as easy connection to infrastructure supply networks. The trend accelerated in the United States in the 1930s, through the National Housing Act of 1934, promoting the "free-standing, owner-occupied, single-family home in the suburbs" [11]. Since the 1950s in the USA, the 1960s in Europe and the 1980s in parts of Asia and Latin America, urban sprawl increased even more with car growing ownership allowing to settle wherever one wants, fostering additional extension of street networks, again pushing urban sprawl. Industrial deconcentration contributes also to sprawl in the large urban agglomerations [12].

In emerging countries, urban sprawl started as a mass phenomenon in the late twentieth century, building huge new metropolitan regions, often within one decade-triggered through massive rural population migration to the cities (c. f. [13]). This leads to the growth of informal settlements resulting in large, sometimes rather dense, squatter dwellings close to the city centres (especially in Latin America) or at the outskirts of the cities [14]. Squatter dwellings were first built with sheds, which were particularly transformed later into basic buildings, partly accepted, legalized and supplied with regular roads, water pipes and power lines (c. f. [15]).

A major pull factor of urban sprawl is, no doubt, the lack or insufficiency of strict planning guidelines and urban development policies, which do not control land consumption in an appropriate way.

\subsubsection{Densification}

Densification in centres is triggered by the land price gradient. Increasing densification is constantly accelerating the property prices (c. f. [16]). Expansion of the service sector-banking, 
insurance, ICT and governmental and urban administration - is enhancing densification. The most densified blocks often evolve in areas of good accessibility, close to higher capacity transportation hubs, with high visiting frequency and increasing opportunity to attract new employees, business partners and clients or to allow fast traveling to business partners.

While density is increasing in the centres, in the entire urban agglomerations, the density is decreasing due to accelerated dispersion. Bertaud [17] showed this by an impressive image (see Figure 1), comparing population distribution in seven agglomeration areas. The distribution of the working population would show a similar pattern although the density gradient will be higher as office space is even more concentrated in urban cores.

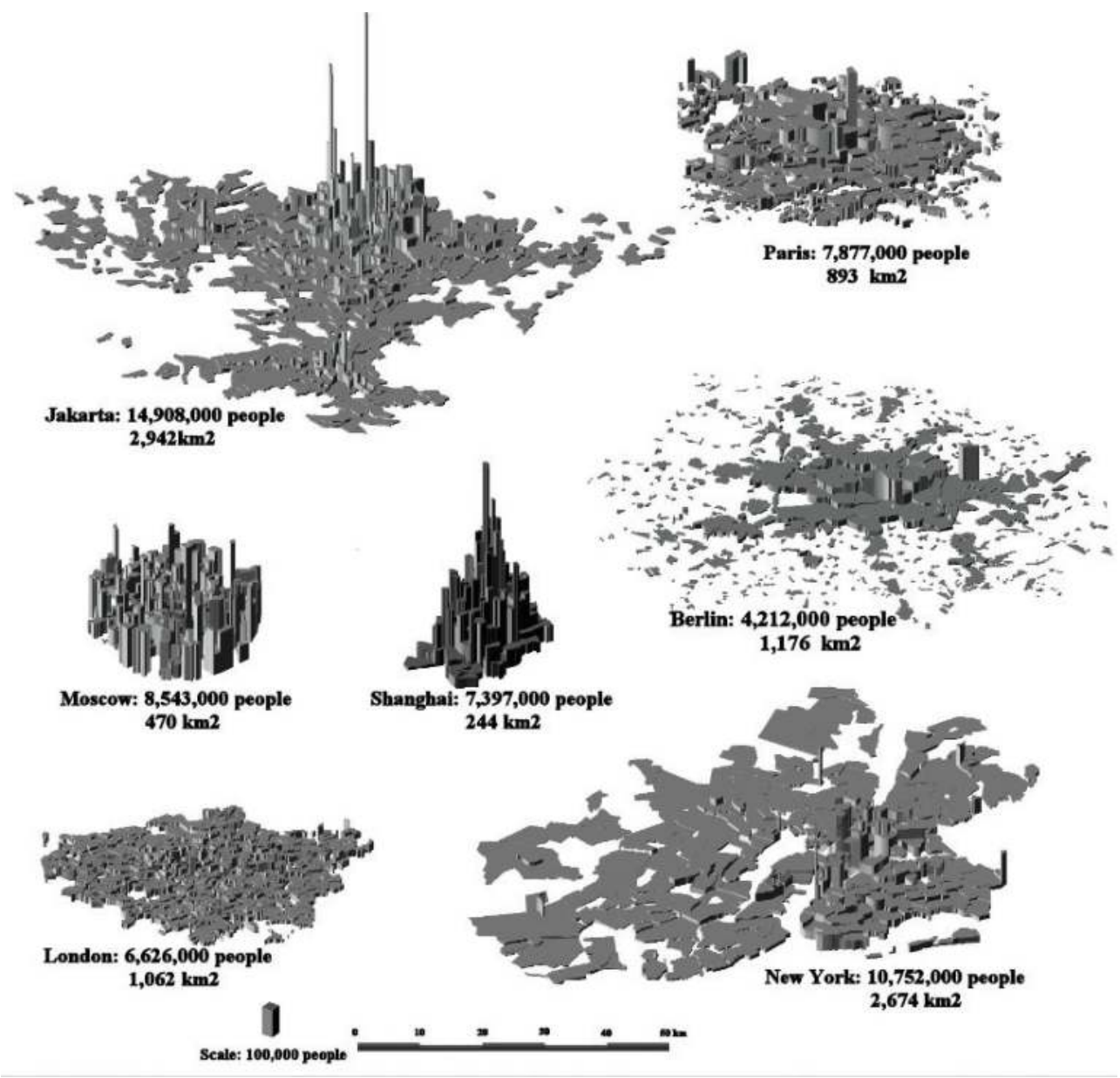

Figure 1. Population distribution in seven urban agglomerations. Source: Bertaud [17]. 


\subsection{Socio-spatial structures and dynamics: segregation, gentrification and aging}

\subsubsection{Segregation}

Segregation - unequal distribution of social groups - is common in urban agglomerations. In small cities, only little segregation of national or ethnic groups is observed, as the number of newcomers is too small to establish a separated community. Metropolitan regions are migration targets for many foreign immigrants as they expect there higher chances to meet fellow citizens and find familiar infrastructure that makes it easy to settle, to get support and advice, to find jobs, to adapt and to integrate (c. f. [18]). There ethnic and national differences play a more important role: as the size of national and ethnic groups is big enough to build clusters with own identity (c. f. [19]). Thus, national or ethnic quarters occur with own shops, restaurants, leisure opportunities, social infrastructure, churches or mosques and finally services like native speaking lawyers, doctors and even newspaper publishers.

\subsubsection{Gentrification}

Gentrification is the process by which deprived urban neighbourhoods experience a reversal, reinvestment and in-migration of middle class to upper middle class population (c. f. [20, 21]). It is the effect of more wealthy people who show new demands for high quality apartments and living areas. This process is more distinct in urban agglomerations as migration pressure of wealthy people is higher and social mobility (through raise of income and change of status) is higher too, because of more earning opportunities in these larger economic zones.

Gentrification can be seen as a negative or positive process: as displacement of the urban poor and destruction of indigenous social communities (c. f. [20]) or as economic revitalization of urban spaces (c. f. [21]), driven by wealthy classes and property developers. An issue, which is in urban agglomerations, with a vibrant housing market is more important. In smaller towns, gentrification plays a minor role, as there is less demand of wealthy classes for high quality housing.

\subsubsection{Age distribution}

The stages of life course (childhood, youth, working age and aging) play a certain role in todays' urban agglomerations. Both-increase of the number of the elderly and of young ones-can be observed in cities, depending on the age structure of the nation and the immigration pressure. In mature industrialized countries with small birth rates, population structure is frequently aging if only little immigration takes place. In emerging countries with high birth rates and in urban areas of developed countries with high immigration rates, the share of young population is growing, attracted by urban areas when searching for higher education, better housing possibilities and workplaces (c. f. [22]). Age group distribution patterns are fluid and differ over time. New housing areas lead during growth periods to homogenous age structures with young singles or families in their early 1930s and small children. In cities where less relocation within a life course takes place, like in central Europe, the age structure pattern remains may cluster into homogenous groups over several decades (c. f. [23]). 


\subsection{Functions, interactions and traffic}

The functional urban region-and urban agglomerations are highly interlinked functional areas-provides complementary functions of different levels at different places to supply the population with all necessities - ranging from residential function to workplaces, to education, shopping and using various services. Making use of these functions requires communication or traveling between the places where those functions are provided.

\subsubsection{Functions}

Referring to Christaller's Central Place Theory [24, 25], explaining spatial arrangement, size and function provision of settlements, there exists a hierarchy and pattern of towns and cities, which provide, depending on size, a range of services for the city and the adjacent service, administration and market area. Simple everyday services like food stores, kindergartens and elementary schools can be found in low-ranked Central Places: settlements, serving the local population and the surrounding area within small distance. Occasionally, demanded specialized services - hospitals, colleges, province administration-are located in higher ranked Central Places: mid-sized and larger towns, serving the population of a larger area-e.g. a province - requiring some traveling. In highest ranked Central Places: large cities with high level services - specialized clinics, universities, national museums, ministries and central governmental bodies - which supply the population of a large area, even a country - are found.

Urban agglomerations allow providing services of all hierarchies up to the highest one in an efficient way, as the different hierarchical services are located within small distance, and supply a large number of people, living or working closely together.

\subsubsection{Interactions, infrastructure and traffic}

Distributed functions in metropolitan regions require more interactions-people flows (shopping, learning, commuting, relocation, etc.), business linkages (supply chains, goods flow, retail, services) - and infrastructure to enable these interactions: Traffic and communication infrastructure, energy and technical services infrastructure and shared social and administrative services. As urban agglomerations are faster growing than standard cities, these services must grow fast too and must be well maintained for sufficient supply, which is again increasing the attractiveness of the agglomerations, at least today.

Urban agglomerations observe high traffic loads frequently causing heavy congestion problems [26]. Compared to the number of inhabitants, the traffic volume is less as the density is higher, the functions are located closer, travel distances are shorter and the public transport share is much higher, at least in the central areas of those metropolitan regions. So, larger and denser metropolitan areas do not mean more car traffic [27]! Building density and thus functional density can significantly reduce traffic, as closely allocated functions provide sufficient supply within short distance, which allows walking for shopping, leisure facilities, schools, etc. instead of driving. Central areas are good examples to enable car-free living. Especially in Europe, remaining medieval structures in many town centres have often hindered to evolve "car-friendly" cities. 
Local traffic varies depending on the layout of neighbourhoods and function allocation. Transregional traffic is the effect of large distance mobility demand. Here, it is important to distinguish between monocentric and polycentric agglomerations - the monocentric ones target more the centre, but show less traffic loads because of less transregional transportation requirement, while the polycentric ones show distributed traffic loads because of wider distance and higher transportation requirement (c. f. [17]).

\subsection{Policy: spatial impact on urban expansion patterns}

Urban agglomerations are driven by administrative structures distinguishing the areas of responsibility and by planning policies establishing the administrative structures.

The government systems and planning policies differ substantially between countries depending, e.g. on the number of intermediary planning authority levels, which has some effect on the development of urban agglomerations. Political and administrative borders may thus lead to lacking planning guidelines, which may result in uncoordinated urban region development-urban sprawl is one severe problem directly caused by uncoordinated spatial planning or lack of interplay between government levels.

Based on the planning power of local and regional government levels, one can distinguish between centralized and decentralized planning systems. The interplay of government systems and overarching planning policies show the potential of the public role to manage and control urban agglomeration development, which can range from no control to full planning control covering the entire region (c. f. [28]). Agglomerations cover usually not just one administrative entity as they are growing beyond the city borders. They cover clusters of administrative entities: in case of monocentric agglomerations, the core city and surrounding peri-urban municipalities and in case of polycentric agglomerations, several core cities and secondary cities.

In countries with weak national to regional planning power and strong local power, local policy makers focus on their own territory resulting in less coordination to develop the parent region. The focus on municipal policies leads also to less transboundary or to divided public transportation networks. This triggers mobility behaviour towards private car use, which again accelerates urban sprawl.

The authorities of several cities embedded in urban agglomerations have learned from the past and established common governance bodies for the agglomeration region as well as regional transportation organizations providing a better framework for regional development (c. f. [29]).

\section{Urban agglomerations in Europe}

Urban agglomerations in Europe show frequently transnational structures, which grew beyond national borders due to dense distribution of cities in small nations. Despite this transnational growth, where cities profit from each other, being part of a large conurbation, they are also urban economies competing with each other while they collaborate.

The "Blue Banana," the name for Europe's largest transnational conurbation, created by Brunet [30], comprises Greater London; the Dutch Randstad region in Amsterdam; The 
Hague, Rotterdam; the Brussels agglomeration; the German Rhine-Ruhr conurbation from Dortmund via Frankfurt to Stuttgart, the Swiss Basel-Zurich agglomeration and, finally, the Milan urban region in Italy. Recently, the "Sunbelt" from Milan to Valencia and the "Yellow Banana" from Paris to Warsaw were identified as new transnational urban agglomeration axes [31].

Besides these "bananas," many more urban agglomerations and functional urban areas (FUAs) can be found in Europe although they are smaller than the transnational ones. Nearly each European larger capital city has evolved as urban agglomeration (see Figure 2).

\subsection{History of urbanization: the nuclei of urban agglomerations in Europe}

About 1000 years ago, Europe starts becoming urban. Between 1000 and 1300, Europe acquired an urban system dominated by typical producer cities, which prospered in spite of Europe's political fragmentation. In fact, this fragmentation was enhanced during the rise of independent city-states or cities with a large degree of local authority. The industrial revolution developed rapidly in England during 1750-1850 and stimulated growth of cities and urban agglomerations. In 1801, 17\% of the European population lived in cities; by 1851, it was $35 \%$ and by 1891 , it was $54 \%$ [32]. All cities and agglomerations show similar dynamics: moderate growth inside the core areas and extended growth of the outer urban region.

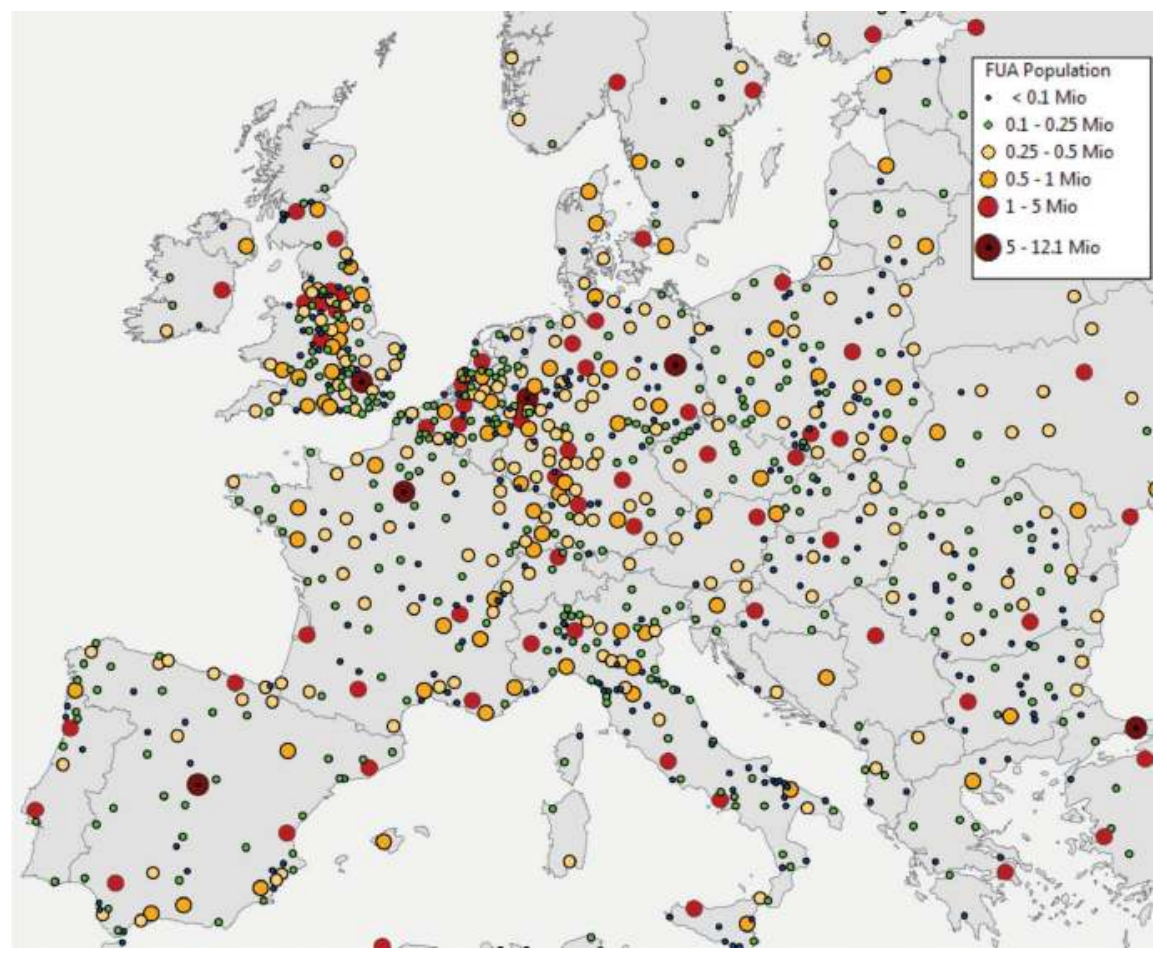

Figure 2. Functional urban areas (FUAs) in Europe by population numbers. Sources: Various European Statistical Data; mapping by Mario Köstl, AIT. 
London and Paris are the two European agglomerations of outstanding size, forming a monocentric core area incorporating during their growth a range of small towns within the outskirts building the agglomeration.

London was rapidly rising after 1500 in importance among Europe's commercial centres. Trade expanded beyond Western Europe, and monopoly trading companies were established in London. Immigrants arrived from Britain and from abroad. The growth of population and wealth of London was fuelled by coastal shipping. The population rose from 50,000 in 1530 to about 225,000 in 1605 [33]. During the 19th century, a network of railways accelerated the growth of the suburbs of Greater London, from where middle class people commute to London centre, while the low-income remained living in the inner city areas. As capital of a large empire, London became also a target for immigrants from the British colonies and Europe [34]. In 1801, Greater London reached around 1.2 million inhabitants, where the outer London's share (the population living outside the London city borders) was $15 \%$. In 1901, the city grew to a population of 6.2 million, where the outer London's share reached 22\%. In 2011, Greater London hosted 8.2 million people, where the outer London's share reached around 60\% [35].

Paris show similar growth dynamics. During the middle ages, Paris was an important commercial centre and the largest city in Europe. Under Georges-Eugène Haussmann, Prefect of the Seine, the Paris centre was rebuilt until 1870 with wide avenues over forming the earlier street layout. In 1860, the city expanded to its present administrative area. Around 1800, Paris had 550,000 inhabitants; after the extension of the city boarders, Paris inhabited 1.7 million people, Paris urban region had 2 million inhabitants and the outer Paris share reached 15\%. In 1911, Paris urban region had 4.5 million people, where the outer Paris' share was 35\%. In 2010, Paris urban region reached 10 million people, where the outer Paris' share was ca. 70\% (numbers reconstructed by Ph. Julien from INSEE). Today, Paris' agglomeration is 27 times larger as the city itself [36].

The Rhine-Ruhr metropolitan region is one of the large polycentric metropolitan areas with several cities as nuclei with no real prime city, hosting more than 11 million inhabitants and covering an area of $7.110 \mathrm{~km}^{2}$. The population dynamics history is not so well documented as the growth of the metropolitan region is based on the moderate but steady growth of many moderate sized and smaller centres. Today, 10 moderate-sized cities (with several 100.000 inhabitants) are part of this metropolitan region: Dortmund, Bochum, Essen, Duisburg (Ruhr Area), Mönchengladbach, Düsseldorf, Wuppertal, Leverkusen, Cologne and Bonn (Rhine Area). In the south, the Rhine-Main metropolitan region has evolved with Frankfurt, Offenbach, Wiesbaden, Mainz and Darmstadt as larger cities. The region is well connected through a very dense motorway and railway network and interrelated by dense commuter flows. Further close connections have been established to the neighbouring Randstad- and Brussels agglomerations [37].

\subsection{History and dynamics: patterns and triggers shaping growth}

The ancient cities in Egypt, in the Greek and Roman empires, often linked to military camps, show a strict geometric pattern - gridded inside their boundaries. Since the middle ages, circular boundaries turn up as a frequent shape representing a natural bound of any city, which is based on some central focus, distorted by terrain, rivers and large distance routes, connecting cities. [38]. Towns started evolving as fortresses or were built around fortresses with walls to protect the citizens. Inside the walls, the cities grow and densify, building irregular shaped blocks and narrow 
streets around the centre, which is the market place or the main church place. The old city was a walking city, allowing to buy the necessary things and to work in close distance to the living place.

Cities have been connected though a star-like road network with neighbouring villages and further cities in wider distance. The radial major road network have been superimposed by secondary places, which serve as sub-centres for neighbourhoods or outskirt areas, being the origin of secondary again star-like street networks inside the built-up area. This structure strengthens the centre function of urban cores as well as functions of the sub-centres and triggers later the layout of public transport systems. The secondary street network provided new connections between the sub-centres, connections which are the origins of the ring road systems around the centre.

In the late nineteenth century, the local street network shaping the villages outside the ancient boundaries of the large cities was replaced frequently by a gridded block system to develop efficient housing for the growing population. Between the 1950s and the 1980s, these structures have been further superimposed by large ring roads or tangential roads outside the core cities (e.g. in London, Paris, Munich, Vienna).

The railway systems, set up in the nineteenth century by private companies, who developed usually one certain network branch, supply a particular suburban area, each railway line with its own terminus, not inside but around the city centre. These systems triggered the development of inner city tram and metro lines, which connected the terminus stations in all larger cities-e.g. in London, in Paris, in Vienna or Berlin (c. f. [39]). At the "rural end" of those network branches, the railway terminals in the peri-urban area provide connectivity with the core city triggering the transformation of former rural villages to small towns, securing access to workplaces and functions of the core city before the era of private car ownership.

Typically, Europe's quite public transport-oriented metropolitan regions are now public transportation organizations with a common tariff system, which allows using one ticket for traveling in the region, while using trains, metro lines, busses, etc. from different companies.

\subsection{Socio-spatial structures and dynamics}

In the European metropolitan regions, the structures are similar as described in the introduction. Wealthy classes move towards refurbished prestigious blocks or high quality, green areas close to the city centre. Inner city gentrification can be observed triggered by upper middle-class population to benefit from close central core services and various location factors (e.g. restaurants, shops, leisure areas, transportation hubs). The lower middle class moved to the attractive outskirt areas-either in sub-centres with sufficient infrastructure and public transport connection or in case of less income "just" to any green area in quite far distance to the city and with weak access to public transport infrastructure (c. f. [3]).

Segregation is a particular topic: the more people from abroad are moving to the city, the more mono-ethnic and mono-national clustering takes place, chasing away the origin population.

Informal housing was long time not an observed issue in Europe's urban agglomerations. Only in some Balkan countries (most affected are Albania and Serbia, but also Romania and Greece) and in the Caucasus countries (e.g. Moldova, Armenia, Kazakhstan, Kyrgyz Republic), this phenomenon occurs (c. f. [14]). 


\subsection{Functions and relations, communication and interaction}

While monocentric agglomerations include all functions of a traditional city within its borders, polycentric agglomerations show some distribution of functions between the centres. For instance, the adjacent Rhine- Ruhr and Rhine-Main metropolitan regions show a certain distinction into heavy industry production areas in the northern Ruhr valley and in service centres in the central area-among them Frankfurt as a European banking centre or Bonn as former administrative centre of (West-) Germany and high value industry (cars, machinery, ICT) in the southern part (c. f. [37]).

The distribution of functions over a wider area requires more interactions, which are raising the traffic load in the metropolitan region. Therefore, the road traffic loads are high and heavy congestion problems are frequently observed-on the highways as well as on the inner city major street networks, although the urban public transport share is relatively high.

\subsection{Policy: spatial impact on urban expansion patterns}

European urban agglomerations are particularly driven by administrative structures and planning policies related to these administrations.

In the introduction, the relative power of the local and the sub-national (regional) levels of government has been addressed as effect of different centralized or federal planning systems. This is of particular interest in the Europe with its small-scale system of many small countries - all with different governmental systems, which show a range of centrality to federalism. Countries with central administration like France allow easy development of common regional planning strategies for the entire urban agglomerations (c. f. [28]). However, even there, city planning is quite independent and neighbouring villages follow their own strategies, although they are forced to respect the national or provincial planning framework. In countries with a strong power for local political entities, like Germany or Austria, the local policy makers feel responsible for their own territory, which leads to more competitions and less collaboration, where it is hardly possible to develop strategies for the entire urban agglomeration. Details can be found in Section 1.

In countries of the former Soviet Union influence sphere like Poland or Hungary, liberal governance structures turn up as the opposite of the former totalitarian framework conditions. This leads to some extent to a reduction of public planning power allowing private developments, not all time in line with the national legal systems, by ignoring zoning regulations and creating gated communities (c. f. [40]) and uncontrolled sprawl.

\section{Urban agglomerations in Asia: focus Iran}

\subsection{History of urbanization}

Iran is one of the oldest and culturally richest civilizations in the world. Shoush, Hegmataneh, Pasargad and Takht-e Jamshid were well-developed ancient Iranian cities, which can be perceived as the origin of Persian urban planning resulting as a major influence in shaping an urban tradition addressed today as the Islamic city (c. f. [41, 42]). 
Iran experienced of expeditious urban population growth after the 1940s, which influenced the process of planning, development and new cities (c. f. [43]). Today, Iran is a modern developing country with the second largest population and the second largest area within the Middle East. Iran hosts the greatest number of cities above 1 million inhabitants in the region: 7 out of 28 [42].

During the past 5 decades, Iran is experiencing the population shift from rural areas along environmental, social and economic development by $68.5 \%$. While there are many benefits of efficient cities, we need to recognize this rapid, often unplanned urbanization that brings different risks such as critical infrastructure, cultural heritage and the potential for devastating spread of disease [42].

When discussing urban agglomerations in Iran, Tehran with 8.4 million inhabitants within the city and 14 million within the agglomeration [43] is the outstanding example.

The city of Tehran was first mentioned around 1100 AD in the book Farsname. Its origin go back to an oasis at the foot of the Alborz mountains. Tehran is located $20 \mathrm{~km}$ north of the city of Ray, which was destroyed in 1220 by the Mongols, causing a shift in the settlement focus in favour of Tehran. Tehran, embedded in a favourable climate and supplied with adequate water resources and, moreover, located along the formerly most important West-East trading route of the Middle East, the old silk road, emerged after its appointment to the capital of Iran in 1798 (instead of Shiraz) during short time as centre of administration and finance of the country [44].

The historic Iranian cities are, like many Arabic cities, walled cities-because of defense and environmental reasons (shading through, protection against desert sand). In 1874, Tehran was provided with a new city wall covering an area of around $20 \mathrm{~km}^{2}$. With this extension started a functional differentiation both within the city and in its surrounding area. While the south manufactories and smaller industries have been established, the northern districts show residential areas with luxury shops for the relatively wealthy upper class. Urban growth accelerated in Tehran after the destruction of the old city wall in 1934 during the first Pahlavi era.

After the 1960s, strong increase in population numbers lead to a big construction boom in Tehran and thus a change of the old structure. This contributed to the intensification and production expansion of the economic sectors and to intensify the building activities and industry's desire for concentration. Originally pure residential and commercial settlements were by the immigration to industrial zones, whereby the growth direction through the arterial roads (primarily in west direction, towards Karaj). Old villages embedded in the area were overrun by this development and are today limited "historic islands" in a purely industrial-commercial environment [44].

After the 1978, Khomeini revolution peripheral developments took place by copying western development models - in Tehran, but more or less in all Iranian cities (c. f. [45]). Standardization of urban systems, widening of streets to facilitate vehicular movement, density increase and construction of elevated highways and bridges which penetrated the urban fabric and public and private realms are some examples.

Tehran is now among the world's fastest growing cities. In the early 1940s, Tehran's population was about 700,000. By 1966, it reached 3 million, and by 1986-during the Iran-Iraq warintensive migration lead to a population increase of up to 6 million. Today, Tehran's extent is around $1500 \mathrm{~km}^{2}$ and its population is 8.4 million, but the metropolitan region has more than 14 million residents [43], as addressed above. 


\subsection{Development drivers for urban agglomerations}

Under the current economic liberalization process, Iranian cities and especially Tehran have been subjected to dramatic development challenges, which have impact on the urban fabric, and the identity of communities. Urban agglomerations evolve leaving the early walled city concepts.

As effect of insufficient urban planning focusing on road infrastructure and housing, Tehran's downtown area show a weakly organized structure of neighbourhoods providing various functions. A proper centre with a meaningful distribution of functions is missing.

The high-rise building area of Tehran is not in the downtown area, although there are some larger buildings - particularly hotels of international companies built in the 1960s. The most new high-rise buildings are erected as apartment buildings for upper middle-class residents in the northern, elevated area of Tehran, along the Alborz slopes with great views, lower temperature, more humid and green environment.

The pressure on new housing leads to various housing development projects in the western, eastern and southern flat areas around Tehran. The new planned developments are designed for basic residential purposes and do not provide proper further infrastructure and have little access to public transportation, as the private developers consider only return of their investments and do not take into account the entire urban system with functions, relations and thus traffic.

The city is little involved in the development of these areas-public investments refer to roads and power infrastructure. The only social infrastructure erected intensively are shopping malls, which serve as communication and entertainment areas with shops, cafes, cinemas, etc. - again financed with private capital.

As urban development is left to private entrepreneurs, the urban agglomeration shows no proper development direction and is growing more or less randomly. This is somehow supported by the physical framework condition, which is just a flat dry area with no barriers and no attractive features like rivers, lakes, forests, parks, etc. in the south.

Urban development is little regulated, as there exist no zoning maps for the city. High-rise buildings can be erected close to single-family homes, which can be observed frequently in selected districts.

The attractive parts of Tehran are in the north, which are constantly densifying through new high-rise buildings, while the west, south and east of Tehran show urban sprawl, not so much triggered by single-family homes but by medium-sized housing developments, production sites, storage and logistics functions as well as transportation infrastructure.

\subsection{Socio-spatial structures and dynamics}

One of the main objectives of the Iranian revolution was to improve social equity. After the revolution, the composition of society changed to some extent, which was in line with the targets of the revolution: the share of the middle-class composition doubled from $15 \%$ (1979) to $32 \%$ (2000) [46].

Urbanization is rapidly progressing: in 2005 , already $68 \%$ of the population was living in cities, and in 2015, the share reaches $73 \%$. Over the past three decades, the country 
experienced rapid socio-demographic and economic changes. New patterns of internal migration, declining fertility, the current youth peak, an upcoming aged population, as well as the growing number of female-headed households are some of the broad socioeconomic changes (c. f. [47]).

\subsubsection{Social structure and segregation}

In Tehran, one do not find ethnic but social segregation, not forced by some unspoken rules but just by affordability. Tehran shows, similar to the Iran average, a small upper class whose share is stable since the Pre-Revolution era. As mentioned above, this class is living since ever in the north in the hilly areas along the mountain slopes because of attractive landscape, climate, environment and view. Except some bus lines, one can hardly find any public transportation because of the complex terrain requiring to use private cars, which is anyway the favourite mode of transport.

A quite big share of middle-class residents is observed living in the central district of Tehran, where also the governmental and company offices and banks are located.

Quite large fraction of lower middle to low-class inhabitants are living in the outskirt areas particularly in the west and the east were the newcomer residents find affordable housing opportunities.

\subsubsection{Gentrification}

Gentrification is observed in a moderate way, triggered by middle-class population, to benefit from close central core services and various location factors (e.g. restaurants, shops, leisure areas, transportation hubs).

The rents and prices rise and force the lower middle class to leave the area, moving to the west and east outskirt areas.

\subsection{Functions and relations, communication, interaction and traffic}

Iranian cities are very much organized in neighbourhoods, which provide all functions within small distances - this has not changed in general, but the habits of the population have changed-not just using the local functions in close distance but different ones because of various reasons - e.g. distance to working place, different supply structure, different quality, etc. (c. f. [48]).

As mentioned above, markets, bazaars and the shopping malls as descendants are part of the social infrastructure, which serve as communication and meeting areas. While bazaars are traditional, narrow places with a focus on trade, which provide cooling only by shading, air-conditioned, spacious shopping malls, usually with own parking facilities, provide convenient and cooled environments for shopping and dining and thus invite customers to stay (and consume).

Thus, the walkable neighbourhood and city are of less importance. The residents make use of their cars or taxis to reach the different places they want to go. Public transport is less relevant-maybe also because of the supply quality. Public transportation infrastructure supply 
in the Tehran agglomeration is rather weak: eight metro lines, some BRT routes and a considerable number of bus lines, which are supplemented by a large taxi fleet, again privately organized.

In contrast to the weak public transport system, the road network is very dense. The local road structure providing access to the neighbourhoods is superimposed by a wide network of elevated multi-lane motorways in the city with rather few exists and some U-turns (!), which require to drive long distances on the motorway network to reach quite close areas one can nearly reach by walking.

Most people who can afford their own car use it, others use the rather cheap taxis than public transport. The intense use of private cars and taxis causes heavy congestion not only during peak hours but also throughout the day. So, the transportation system is extremely inefficient and it takes much longer to go by car than to take a metro or BRT which their separate bus lanes.

However, public transport is experienced to be less attractive than private transportation, which has also cultural/religious reasons, leading partly to a social divide of men and women in public life where women avoid using public transport.

The effect of the intensive private car use is that Tehran is heavily suffering from smog and dust.

\subsection{Policy: spatial impact on urban expansion patterns}

Urban management is since 20 years organized capacity of communities and grassroots in the management of cities in Iran. After the revolution, Islamic councils have been established both in cities and in rural areas. The councils are directly elected by the people and have selected municipal functions. The countries' policy is framed in 5-year development plans (c. f. [49]).

The history of development planning in Iran started in 1949 with the first development plan. Within this period, eight development plans have been implemented, five of them before and three of them after the 1979 Revolution [50].

With the beginning of the Islamic Revolution, urban development planning was disrupted. The first development plan after the revolution, set up in 1982 and approved in 1988 after a number of changes, stipulated construction of 10 million housing units and overcoming the housing shortage within 20 years [50].

The measures defined by the "Development Plan 1988-93" include granting of easy accessible loans, provision of construction materials at government prices, sale of land at low prices and approval of new housing cooperatives. These measures reduced the housing development costs, increased the number of housing units and led to a horizontal expansion of the cities, reducing housing density [51].

The recent development plan addresses again the rapid urbanization announcing access of all groups of the society to "adequate and decent housing and provision of basic services for all households" as focal points [52].

The government's current planning policy, called PAK (from pasandāz [saving], anbuhsāzi [collective housing], and Kuchaksazi [building small]) which aimed to optimized housing (c. f. [50]). 
It consists of three main doctrines: (1) developing housing provision plans within the framework of a comprehensive social welfare policy, (2) optimum use of market mechanism with little government intervention only in case of market failure, and (3) promoting savings and loans system to enhance the access of middle-income groups to adequate and decent housing (c. f. [49]).

As urban development focuses only on housing, which shall be triggered "by the market," there is little opportunity for strategy-based urban development (c. f. [50]).

\section{Urban agglomerations in Asia: focus China}

\subsection{History and dynamics of urbanization}

China's cities are among the oldest in the world. Banpo, the first Chinese city appeared on the Central plain around the Yellow River more than 6000 years ago. During the Iron Age, or Eastern Zhou Dynasty, a differentiated urban system was established for the first time. The role of the cities, at this time, was defined by the local economy and by their military and administrative functions. In addition, principles for governmental administration and for urban planning were written down for the first time in this period. During, the Qin Dynasty, an administrative system was established, which divided the country into provinces, prefectures and counties. On the top of the hierarchy was the imperial capital, which had not only economic and military functions but was also of symbolic and religious importance (c. f. [53]).

Although, in ancient China, some capital cities had more than one million inhabitants and were bigger than European cities of that time, ancient China was a predominantly rural country. When the People's Republic of China was founded in 1949, the urbanization rate was at $10.6 \%$. Urbanization increased slowly, but steadily during the 1950s, and stagnated during the 1960s and 1970s, when Chinese society was shattered by social experiments like the "Great Leap Forward" (1958-1962) and the "Cultural Revolution" (1966-1976). When the political and social situation developed after Mao's death, the urbanization started to rise again. The incremental transition of the Chinese economy from a planned system to a "socialist market economy" accelerated the growth of the urban agglomerations in and unprecedented way. In 1990, around one quarter of the Chinese population lived in urban area. In only 20 years, this share doubled: in 2011, already more than $50 \%$ of the population was living in urban areas, and the urban agglomerations continued growing (c. f. [54]).

The Chinese government defined the Pearl River Delta, Shanghai and Beijing as future megacities. These megacities were supposed to attract the lion's share of Foreign Direct Investment and to become thus the powerhouses of the Chinese economy. The concept turned out to be very successful. A couple of years later, the Szechuanese cities, Chongqing and Chengdu, were selected to become two inland mega cities, following the example of Beijing, Shanghai and the Pearl River Delta.

Despite negative social and ecological consequences, such as very high levels of air pollution, huge land consumption and loss of cultural and natural heritage, the pace of Chinese will stay rapid in the coming years. 


\subsection{History and dynamics: patterns and triggers shaping growth}

Beijing was founded around 3000 years ago and became capital of China in 1152. Its current urban structure traces back to interventions carried out in the early fifteenth century, when emperor Yongle built the Forbidden City and the Temple of Heaven as the governmental and the spiritual centres of old Beijing (c. f. [55]).

Old Beijing was planned as a system of circular rings: the Forbidden City was in the centre and served as imperial palace until 1911. The Forbidden City was surrounded by the Imperial city as administrative centre, which itself was surrounded by the inner city and the outer city, both of them areas where artisans, craftsmen and traders lived. All circular rings were walled. This urban morphology was comparatively stable over a long time (c. f. [55]).

In the 1960s, the city walls were demolished and later replaced by an urban expressway, the so-called 2nd Ring Road. With this ring road, the concentric development pattern of the historical city was replicated with modern means. Following the increasing urbanization, a $3 \mathrm{rd}, 4$ th, 5th and 6th ring road were added, which structure the urban metropolis. The space between the ring roads was quickly filled up with new developments.

The development of an efficient public transport system started rather late. Before the Beijing Olympics of 2008, there were only few subway lines in operation, thus the urban development could not be concentrated on public transport lines. It rather filled up the space between the ring roads, continuing the concentric development typical for Beijing.

In the past 10 years, the metro system expanded rapidly. It is now, after Shanghai, the second longest metro system in the world, and is expected to further grow in the future. However, the system does not have the typical star structure like European cities, but a grid layout, which is superimposed by two circle lines, reflecting the agglomeration's concentric development.

Shanghai, China's second city, is much younger than Beijing. It was a city of less importance until it became the gateway of several colonial powers to China in the late nineteenth century. Several foreign settlements, so-called concessions were built by the colonial powers adjacent to the old Chinese town. Together, they now form the downtown of Shanghai. A good part of the urban expansion of Shanghai followed the concentric model of Beijing. Also in Shanghai, an efficient public transport network evolved quite late, but it has been widely expanded in a comparatively short period.

A significant difference is however the spatial direction of the urbanization process: As Shanghai is confined by the sea in the south and the east and by the Yangtze River in the north, urban expansion can only move towards west. In this direction, there are several mediumsized cities (like Suzhou, Hangzhou, Changzhou, Wuxi, Nantong) with a strong economy and their own culture and history. Many of these cities are already connected by high-speed railways. They build together with Shanghai, the Yangtze River delta region.

The third urban agglomeration in China presented in this article, the Pearl River Delta, differs significantly from Beijing and Shanghai, as it is a clearly polycentric region called a city network. It comprises several cities in the Guangdong province and the Special Administration Zones of Hong Kong and Macao with in total 63 million inhabitants. The cities in the region 
have very different characteristics regarding history, culture and economic structure. The strong, mainly manufacturing-based economy in the region and the urban growth lead to increasing regional integration and the formation of an agglomeration. Creating connectivity and access is a particular challenge due to the polycentricism. As expressways are frequently congested, there are now plans to connect the metro networks of different cities in the region and to establish a regional network of high speed and commuter trains called Pearl River Delta Rapid Transit.

\subsection{Socio-spatial structures and related dynamics}

In 2016, the Chinese per capita income was 7.5 times higher than in 1996 [56]. This is a spectacular increase in wealth in just 20 years. Nevertheless, there is still a very big difference in the regional distribution of wealth: The household incomes in the urban agglomerations at the coast are much higher than in the hinterland. This leads to strong internal migration flows from the hinterlands to the urban agglomerations.

To control the influx of people into urban agglomerations, the Chinese government uses the so-called Hukou (household registration) system [57]. This system divides the population into urban and rural dwellers according to their place of birth. Citizens with a rural Hukou can under certain circumstances live and work in urban areas, but will not have access to social services in the cities and usually receive less salary than urban dwellers. This creates a big polarization in Chinese cities, as the share of persons holding rural Hukous reaches 30\% and more in some Chinese cities. There is a very lively debate in China on how the Hukou system can be reformed and eventually abandoned. Many Chinese regard it as highly unfair, but it is an open question how urban agglomerations could deal with the influx of more internal migrants once the system is removed.

The Hukou-holding migrant workers are at the bottom of the urban societies in China. Many migrant workers still live in containers on construction or factory sites, physically separated from the city dwellers.

\subsection{Functions and relations, communication and interaction}

In case of the monocentric urban agglomeration of Beijing, nearly all urban functions are concentrated in the core city. The Jing Jin Ji plan aims at reducing the pressure on Beijing by establishing a 130-million capital region, covering three provinces with the city triangle Beijing-Tianjin-Baoding as its core. The new Beijing Daxing airport and the Xiong'an New Area south of Beijing, which shall absorb a significant share of the future urban growth of the agglomeration, are key measures in the development of Jing Jin Ji (c. f. [58]).

As the distances between Beijing, Tianjin and Baoding are between 130 and $200 \mathrm{~km}$, highspeed railways will play an important role in connecting the three cities. The use of high-speed transport to create connectivity and access not just at national level, but also at regional scale is a new strategy for shaping urban agglomerations in China. To a certain extent, it has already been implemented in the Yangtze River Delta around Shanghai, and it will be applied in Jing Jin Ji and the Pearl River Delta. Eventually, the network of high-speed trains will lead to an 
integration of concentric or star-shaped urban agglomerations into a network of cities that will cover most of China. Chinese researchers expect this new development model of a network city to be more efficient than star-shaped or concentric urban agglomerations (c. f. [58]).

\subsection{Policy: spatial impact on urban expansion patterns}

Chinese centralized policy had great influence on shape and development of cities and later agglomerations. The ring structure of Beijing, the economic liberalization with the set-up of special economic zones and the Jing Jing Ji plan are impressive examples of the effects of the national policy and planning strategy.

After almost 30 years of high-speed urbanization, the Chinese government has announced a new era for the development of the urban agglomerations in China called the New Normal. Lower but more qualitative, efficient and innovative growth shall characterize it. In addition, the Chinese National New-Type Urbanization Plan 2014-2020 and the 13th 5-year Plan 2015-2020 suggest a new pathway for urban development in China, with a stronger focus on quality of life and on environmental quality than in the past (c. f. [59]). A better planning and management of urban agglomerations will be of utmost importance for reaching these goals.

\section{Urban agglomerations in Latin America}

\subsection{Development drivers for urban agglomeration in Latin America}

During the past 60 years, Latin-American has experienced very strong structural changes in its social, economic and spatial dimensions, shifting its settlement patterns from dispersed rural arrangements into urbanized or agglomerated concentrations (see Figure 3). Today, 80\% of the Latin American population concentrate in urban agglomerations and this share seems to continue growing (c. f. [60]).

Despite the difficulty to generalize such a diverse (sub-)continent, independent from the Spanish colonial administration since more than 200 years, similar urban patterns of agglomeration and development trajectories and processes can be identified from the second half of the last century until our days. On the one hand, socio-economical drivers, as the very rigid and traditional system based on the socio-economic status differentiation of the population, have been spatially settled, leading to urban fragmentation forms in both sides, the rich protected by fences in gated communities and the poorest hiding in segregated informal settlements. This reality has shaped not only the spatial organization of almost all Latin American cities but also a continental feature, positioning the whole region as the one with the highest level of income inequality of the world.

On the other hand, although exponential urban growth had several positive economic effects, this also caused various negative environmental impacts. It has not been successful per se in influencing political concerns and policy measures oriented to reduce vulnerabilities or improving living conditions for urban citizens in an effective manner. 


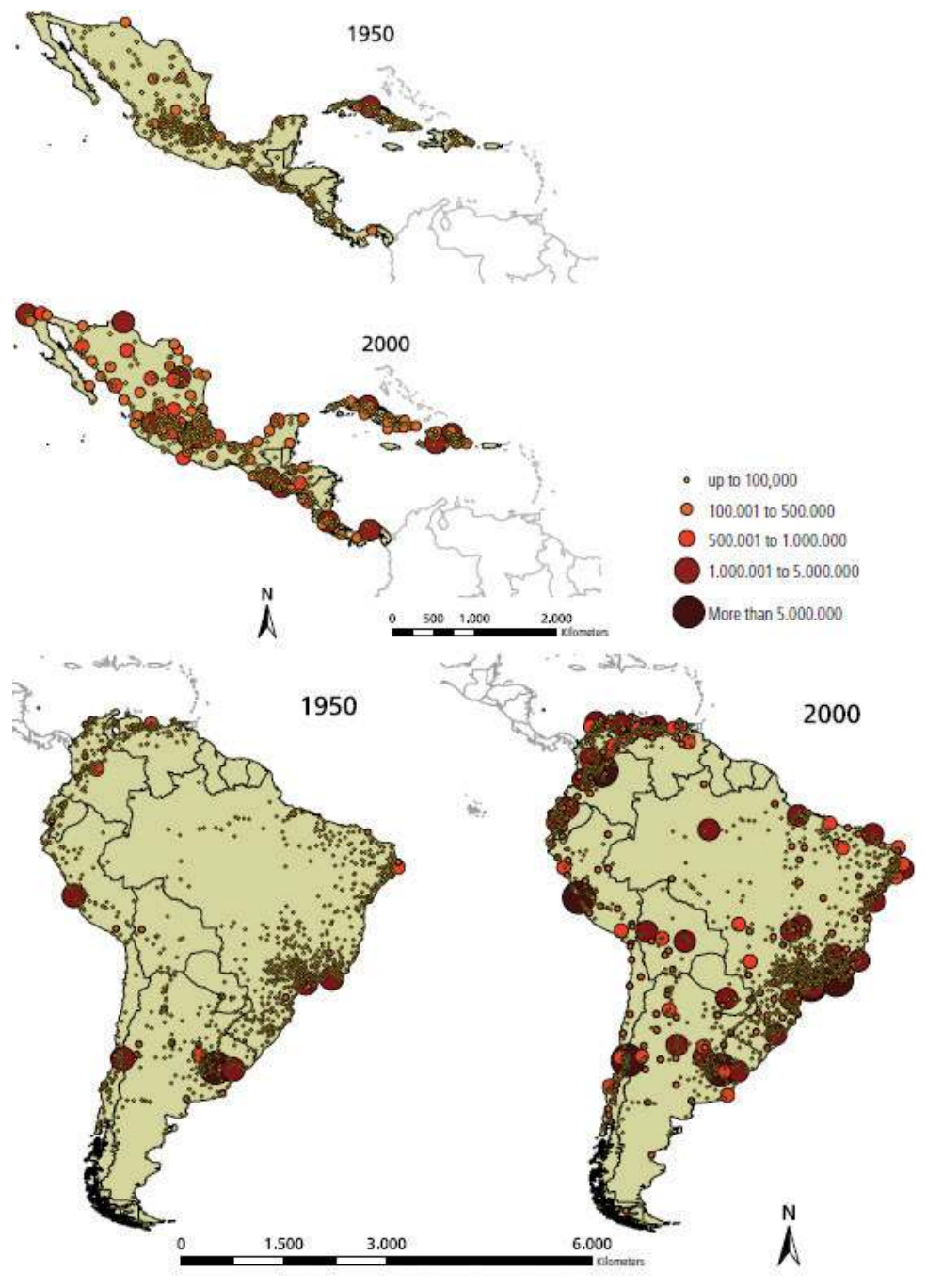

Source: Compuied with data from CELADE, UNDESA and nationa/ censuser.

Figure 3. Latin America and the Caribbean. Cities with over 20,000 inhabitants, 1950 and 2000. Source: UN Habitat [72].

This, in fact, questions the capacity of governmental institutions, particularly in similar spatial distribution and accessibility to public transport, education, health, justice, security and/or even to trade for urban dwellers. "One thing is clear: Latin American nations continue to tackle with many of the same problems they have tackled with for decades - uneven growth with high levels of poverty and the world's highest levels of inequality; ineffective state institutions that deliver limited benefits to often a highly restricted minority of the population" [61]. 
However, evidences from specific institutional and private efforts to update and implement projects and measures oriented to reduce inequality and improve urban environments have been internationally recognized and awarded from Brazil, Ecuador, Chile and Colombia during the last 15 years and should be mentioned due to its relevance and deep positive impacts.

\subsection{Patterns of spatial development in Latin American urban agglomerations}

AAlthough the urban agglomeration process in the region started 65 years ago, it continues expanding at a rate of $20 \mathrm{~m}^{2}$ per minute [62]. During the last years, the development speed started to decline.

Thus, despite there seems to be a deceleration in in-migration rates, while "...in the 1980s, migration from the countryside contributed 36.6 per cent to the growth of urban population in the whole region, in the 1990s this share had fallen to 33.7 per cent" [63], net internal population growth and physical expansion continue rising.

Empirical evidences from different Latin-American cities show similarities in their spatial development patterns and processes, evolving diffuse peripheral fragmentation due to informality development (c. f. [64, 65]) and increasing tendencies of urban sprawl (c. f. [66]), as well as social and spatial fragmentation due to gated communities (c. f. [67-71]).

Although urban sprawl and/or suburbanization phenomena have constantly increase in Latin America ([62]), compact horizontal expansion and densification of the existing built environment keep being the most common growth patterns [73].

In fact, Latin America is still more or less compact, built areas have densified and intensify it uses at the periphery in higher proportion as in the urban centres (c. f. [74, 75]) in "... open-fragmented peri-urban fabric where autonomous elements do not relate to each other anymore..." [76].

This uncontrolled and fragmented expansion process has been observed in almost all countries of the continent, passing the boundaries of the administrative municipalities absorbing and agglomerating other close located settlements and towns in conurbation processes.

Building urban agglomerations through sprawl is in fact the most common urban development pattern in Latin America, and it is one of the reasons of the polycentric structure of the Latin American urban landscape. Metropolitan regions in Latin America bring new challenges at the spatial, the sustainability, the planning and administrative levels, as long as there are almost no mechanisms for integrated governance between different municipalities and territorial institutions (Figure 4).

\subsection{Socio-economical spatial dimensions and vulnerability}

Some roots for higher spatial fragmentation levels, segregation, as well as for the increasing urban inequality can be understood as a spatial effect of a fragmented, stratified society. Stratification as a spatially structured result of socio-economic class differentiation relates to colonial times, where social strata are determined by the person's position at the moment of birth, with little or no social mobility possible (c. f. [77, 78]). 


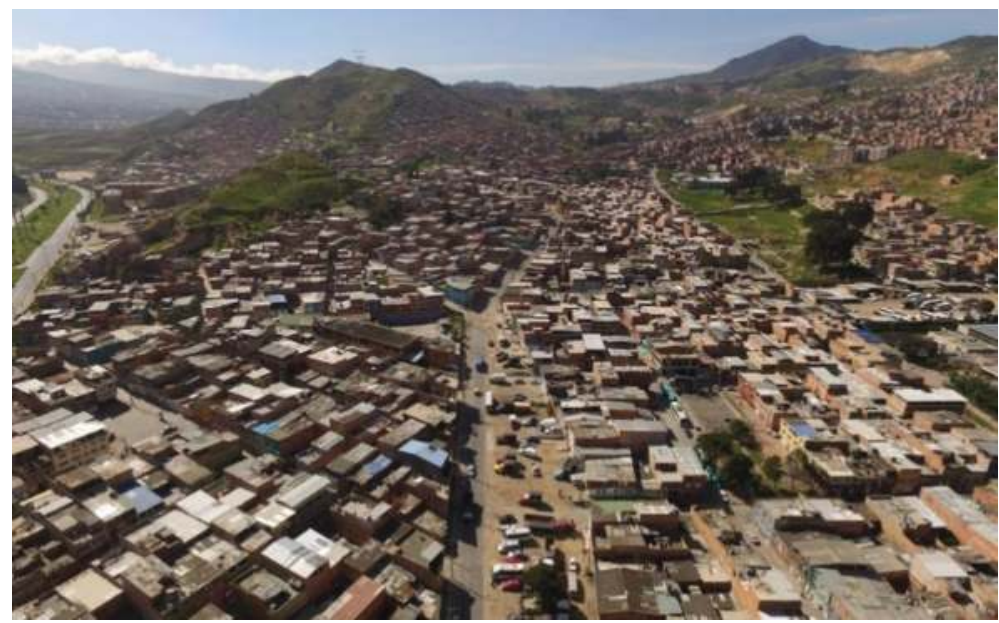

Figure 4. Urban sprawl in Bogota's southeast periphery. Source: Santiago Sanchez Guzman.

With almost one fourth of the entire urban population still living in informal settlements in the region in 2014 [79], levels of urban environmental vulnerabilities thread exactly those poorer and denser populated areas in the outskirts.

Informality, as a result of postcolonial socio-economical dynamics (c. f. [80, 81]), has only consolidated and spread longer since the introduction of neoliberal policies and measures tended towards privatization and economic efficiency (c. f. [69]).

The implementation of neoliberal policies, understood as "the set of policies that were prescribed together as part of a strategy to enhance the role of markets in economic development" [61] in countries like Chile and Bolivia, determined some of the patterns of privatization of infrastructure, social services and even natural resources as tap water provision.

"The process of water privatisation in Chile which began in 1981 under General Pinochet established a model for water management that strengthened private water rights, adopted a market-based allocation system and reduced state oversight. That model became emblematic of neoliberal reforms heavily promoted by the World Bank and International Monetary Fund" [82].

Latin America, as a playground for experimentation of neoliberal reforms since 1976, did not achieve reducing socio-economical gaps between class groups, but on the contrary, contributed to consolidate monopolies and disparities in cities as well as asymmetrical distribution of its services and wealth.

\subsection{Political economic perspective}

"Economic growth is not a sufficient condition for improving the quality of life. Millions can be and have been left out systematically from the benefits of economic growth" [61]. Latin 
American urban agglomerations are a good example of how financial and physical urban growth per see has not been strong enough to reduce poverty and inequality, but on the contrary, has raised uneven development. Development, understood "as a process of expanding the real freedoms that people enjoy" [82], has unfortunately not occurred at the same velocity of the growth and urban expansion rates.

Although the Human Development Index of the region shows still better performance than African Regions, they share the same levels as most Eastern-European and some Asian countries, but are far lower than OECD levels (c. f. $[79,83])$.

Although Latin American political concern has centered during different periods on the discussion of import substitution versus market liberalization, the central problem has not been addressed in improving effectiveness of institutions. "The problem is not 'too much market' or 'too much government'. Rather, it is poorly functioning markets and poorly functioning governments. Both markets and governments need effective institutions to perform well" [61].

Institutional weakness is, by far, one of the most important reasons of the difficulty in monitoring, planning and designing urban growth and has contributed to a lack of participation from civil society in governance processes as well as created the perfect context for illegality.

\subsection{Public transport, housing and social infrastructure}

Latin American agglomerations face big challenges in shortening the distance between socioeconomic classes improving living conditions of its most vulnerable communities and turning actual institutions into more effective active actors for development. Political continuity, or better, the continuity of development policies and projects, is also a key element to accomplish heavy development endeavors and plans as seen in cities like Curitiba, Quito, Medellin and Bogota during different periods. Innovative measures and projects related to urban systems, such as bus rapid transit (BRT), cable cars, improving the accessibility of informal housing areas, public libraries, schools and kindergartens and improving education in those cities, have been only possible due to the political compromise of different administrations to achieve and implement the projects rather than use their own positions to brand themselves.

However, despite those very relevant achievements, the region is still facing big challenges, aiming at sustainable solutions for housing provision in an integrated way, reducing fragmentation and transforming agglomerations into more inclusive, resilient and healthy urban environments.

\section{Urban agglomerations in North America: focus USA}

\subsection{Background: the start of urbanization}

In North America, large urban agglomerations can be observed along the east coast where the first colonial settlements, evolved as trading centres and harbours as transportation hubs to the old world. They have been later connected with the hinterland and the west coast through 


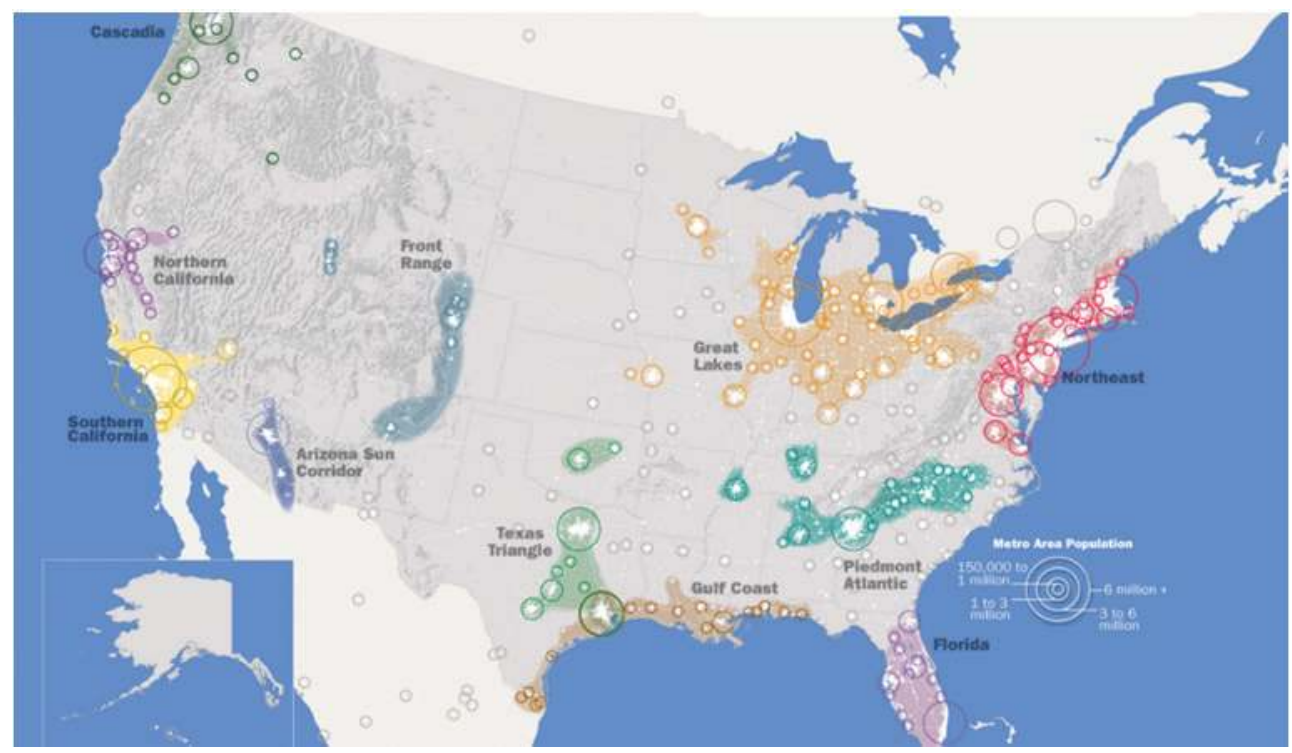

Figure 5. Emerging American-Canadian megaregions as defined by America 2050. Source: Ref. [84].

railways. These settlements with attractive location factors build the nuclei of cities, which steadily grow and merge into large polycentric conurbations. In the mid-west, these dynamics and the drivers behind-harbours at the Great Lakes, trading centres and transportation hubs can be also identified - created e.g. the Chicago-Pittsburgh conurbation ("the Great Lake Megalopolis") as an agglomeration covering several cities like Chicago, Milwaukee, Detroit, Cleveland and Pittsburgh. Along the West Coast, the dynamics turned out in the beginning similar with harbour cities like Seattle, San Francisco, Los Angeles and San Diego, later connected with the hinterland and the entire country through railway lines, which grew first through housing areas and later through industry centres-where the Silicon Valley is the most famous one. As these cities are located in quite distance, they do not evolve polycentric structures but stay as monocentric agglomeration on its own. As Fang and Yu [1] addressed, agglomerations turn out as urban systems with self-sustaining hierarchical structures and functions. This can be observed in the huge Washington, Baltimore, Philadelphia, New York and Boston agglomeration, where each city itself has different core functions: Washington D.C. is the political and administrative centre with historical and cultural heritage, Philadelphia the manufacturing centre, New York is the commercial, service and banking centre, while Boston can be seen as academic centre. Figure 5 gives an overview of the most important urban agglomerations in North America.

\subsection{History and dynamics: patterns and triggers shaping growth}

In the 19th century, growth of cities in Europe and North America accelerated, but reached their peak by the mid-20th century. The West Coast of the USA grew substantially during the years 
until to 1990. North America is now one of the most urbanized regions of the world with about $82 \%$ of people living in urban areas (c. f. [85]).

Growth was always closely related to economic development. Analyses show that larger cities tend to perform economically better and that the future patterns of economic output, the current regional differences in GDP per capita, will persist at least until 2030 for the global north and south. Until the mid-nineteenth century, the city centre was a most fashionable living location. Changes in the transport systems allowed the population not to live in walking distance to their working places, which had a significant impact on the dwelling patterns where people started to seek for neighbourhoods with similar social structure to show and pretend their own status. The wealthy people moved to the attractive suburbs around the urban cores and the low-income population concentrated in less attractive cheaper areas either in downtown or in far distance less attractive suburbs. Due to cheaper but sufficiently still skilled workforce abroad companies start moving to develop areas e.g. in Latin America or Asia and, as jobs disappeared, cities began to shrink in the late 20th century in North America [86].

\subsubsection{Densification}

A reason for densification is often the revitalisation of old historic centres of those cities, which constantly have deteriorated, in the second half of the twentieth century. Major public and private investment was needed to restore the buildings and places to attract new residents, but these investments lead often to a significant increase of lot-prices and reduce the affordability, leading to gentrification and segregation. This dynamic also brings up new pressure to the transport sector and increases the energy demand. The support for housing was mainly given to expand and improve already existing units, which led to a lack of appropriate design principles causing problems such as overcrowding or low privacy. These housing units are also often very vulnerable to environmental disasters. This causes the important challenge that how to raise the social and spatial living conditions in the already consolidated settlements with improved design.

\subsubsection{Segregation}

In the USA, segregation is traditionally associated with racial segregation. Officially, it is forbidden but can be still observed. Racial segregation starts centuries ago and continues during the rapid urbanization in the early twentieth century, which was associated with a significant increase of European immigrants and African-Americans, both clustered because of their limited income in neighbourhoods with poor housing. A further driver was the school segregation, which was legal until 1954 in the USA, but still is persistent due to continuing segregated residential patterns [87]. Racial segregation has diminished significantly since 1960s but the African-American population still remains the most segregated racial group and is hypersegregated in the largest urban agglomerations (c. f. [88]). Significant spatial segregation can also be found for Hispanics and Asians. Native Americans are segregated but to a much lower extent. In contrast to racial segregation, the separation of income grew during the last decades. More than half of all low-income working families are racial minorities. 


\subsubsection{Gentrification}

Gentrification is a well-discussed issue in the USA, which leads to residential segregation. A recent study in 2015 found that gentrification, as a national problem, is actually less pervasive than perceived. But in urban agglomeration areas, gentrification is a significant issue, where rising housing costs are forcing the low-income classes to relocate to cheaper, less attractive areas. Recent research discusses that trends towards gentrification are only one part of the dynamic. Youthification, an increasing presence of young adults within a given neighbourhood, can be also seen as a trend in North American cities. This trend is uneven distributed, whereas it seems that cities with the highest presence of you adults are those rich in amenities and opportunities but with lower cost of living and dense vibrant urban neighbourhoods (c. f. [89]).

\section{Conclusions}

The structures, dynamics and general challenges of urban agglomerations in the addressed continents are not that different, unless some phenomena do not occur in all metropolitan regions (e.g. informal housing, ethnic segregation, cultural/religious barriers, etc.). However, the ways to cope with the challenges and the success are different and the agglomerations can learn to some extent from each other.

In all continents, monocentric agglomerations show a more simple structure and more concentric development dynamics and frequently a centralized municipal or regional government, which makes it easier to elaborate integrated development concepts for the agglomeration that consider the region as single entity and addressing functional and relational issues from an internal perspective. Polycentric agglomerations consist of various cores with own municipal administrations, which require intensive collaboration and coordination to make the urban agglomeration a success.

Strategic urban planning is necessary for urban agglomerations to reduce urban sprawl to a minimum and to provide a proper distribution of functions, which allows easy supply of the population with the relevant services through a walkable city or at least a city of short distances. This would reduce traffic and thus congestions and would mitigate air pollution and thus increasing environmental and life quality.

Sufficient housing development is a crucial point as all agglomerations show immigration pressure and growth. Smart social housing is a necessity to avoid the appearance of deprived areas in the future. Segregation can be avoided by a smart mixture of different housing qualities and by a smart distribution of urban functions and infrastructure, serving all social classes in the same way. Participation in planning processes helps to develop common solutions and to achieve better acceptance in decision-making.

Gentrification is a mechanism which can be used actively to improve certain areas, financed by private investors, but negative effects should be mitigated, e.g. by establishment of local social housing estates in the area to accommodate those which must leave their-now 
renovated and expensive-apartments because of loss of affordability. This also supports the addressed mixture in housing qualities avoiding full segregation.

A social divide must be avoided as far as possible not just through provision of mixed-use areas but also through education and provision of equal opportunities for all, which is easier in agglomerations than in small towns. Skilled people secure economic development in the agglomeration as they attract new companies to establish production sites and thus gain new income in the area.

Traffic is the final big topic in urban agglomerations. The European style star-like major street networks promote the city centre as central place and promote public transport service to provide sufficient accessibility to the relevant services located in the target region, as well as to the housing districts as source regions. Grid-like street networks mitigate the location quality regarding centrality in the core city centres. Central functions can be placed anywhere and need just a road network to provide accessibility, less usable for walking or cycling short distances.

Public transport is a major issue, which makes accessibility of functions, interactions, commuting and thus urban life easier. As the size of the agglomeration increases the risk on congestion, high quality public transport services are the more important, the larger the urban agglomerations are.

\section{Author details}

Wolfgang Loibl*, Ghazal Etminan, Ernst Gebetsroither-Geringer, Hans-Martin Neumann and Santiago Sanchez-Guzman

*Address all correspondence to: wolfgang.loibl@ait.ac.at

AIT Austrian Institute of Technology, Vienna, Austria

\section{References}

[1] Fang C, Yu D. Urban agglomeration: An evolving concept of an emerging phenomenon. Landscape and Urban Planning. 2017;162:126-136. DOI: https://doi.org/10.1016/j. landurbplan.2017.02.014

[2] Knieling J. Metropolitan regions: Definitions, typologies and recommendations for development cooperation. Deutsche Gesellschaft für Zusammenarbeit [Internet]. 2014. Available from: https://www2.giz.de/wbf/4tDx9kw63gma/Metropolitan-Regions_ Definitions_Typologies.pdf [Accessed:Sep 10, 2017]

[3] LoiblW, Tötzer T, Köstl M, Steinnocher K. Simulation of polycentric urban growth dynamics through agents - Model concept, application, results and validation. In: Koomen E, Stillwell J, Bakema A, Scholten H, editors. Modelling Land-Use Change - Progress and Applications. Dordrecht: Springer; 2007. pp. 219-235. DOI: 10.1007/978-1-4020-5648-2 
[4] Bogue DJ. Principles of Demography. New York: Wiley; 1969. (DLC) 68026847

[5] De Jong G. Expectations, gender, and norms in migration decision-making. Population Studies. 2000;54(3):307-319. DOI: 10.1080\%2F713779089

[6] Richardson HW. Economies and diseconomies of agglomeration. In: Giersch H, editor. Urban Agglomeration and Economic Growth. Berlin-New York: Springer; 1995. pp. 123156. DOI: 10.1007/978-3-642-79397-4_6

[7] Sfetcu S. Economies of Agglomeration [Internet]. 2014. Available from: https://www. setthings.com/en/economies-agglomeration [Accessed: Sep 10, 2017]

[8] Straszheim R. Urban agglomeration effects and employment and wage gradients. Journal of Urban Economics. 1984;16(2):187-207. Available from: http://www.sciencedirect.com/science/journal/00941190/16/2

[9] Bhatta B. Analysis of Urban Growth and Sprawl from Remote Sensing Data. BerlinNew York: Springer Press; 2010. DOI: 10.1007/978-3-642-05299-6

[10] Bruegmann R. Sprawl: A Compact History. University of Chicago Press. Chicago, IL 2005. ISBN: 9780226076904

[11] Hornstein JM. A Nation of Realtors: A Cultural History of the Twentieth-Century American Middle Class. Durham, NC: Duke University Press. 2005. ISBN: 978-0-8223-3528-3

[12] Harris J. Urban and industrial deconcentration in developing economies: An analytical framework. Working Paper 53, Dep. of Econ. Cambridge: MIT; 1970. Available from: https:// dspace.mit.edu/bitstream/handle/1721.1/64336/urbanindustriald00harr.pdf?sequence=1

[13] Kassa F. Growth rates and effects of urban sprawl in developing countries, the case of Addis Ababa Ethiopia International Journal of Area Studies. 2014;9(2):135-151. DOI: https://doi.org/10.2478/ijas-2014-0009

[14] UNECE. Informal Settlements in Countries with Economies in Transition in the UNECE Region [Internet]. 2012. Available from: https://www.unece.org/fileadmin/DAM/hlm/documents/Publications/Literature_Review_on_Informal_Settlements.pdf [Accessed:Oct 11, 2017]

[15] Barreto TB. Obstacles to Legalization of Squatter Settlements in Venezuela [Internet]. 2001. Available from: http://www.lincolninst.edu/publications/articles/obstacles-legalization-squatter-settlements-venezuela. [Accessed: Nov 21, 2017]

[16] Alonso W. Location and Land Use: Toward a General Theory of Land Rent. Harvard: Harvard University Press; 1964. ISBN: 9780674730854

[17] Bertaud A. Metropolis: A Measure of the Spatial Organization of 7 Large Cities [Internet]. 2001. Available from: http://alainbertaud.com/wp-content/uploads/2013/06/ AB_Metropolis_Spatial_Organization.pdf [Accessed: Sep 15, 2017]

[18] Zetter R, Griffiths D, Signona N, Flynn D, Pasha T, Beynon R. Immigration, Social Cohesion and social capital [Internet]. York: Joseph Rowntree Foundation; 2006. Available from: https:// www.jrf.org.uk/sites/default/files/jrf/migrated/files/9781899354440.pdf [Accessed: Sep 15, 2017] 
[19] Gordon I, Monastiriotis V. Urban size, spatial segregation and inequality in educational outcomes. Urban Studies 2006;43(1):213-236. DOI: 10.1080/00420980500409367

[20] Atkinson R. Measuring gentrification and displacement in greater London. Urban Studies. 2000;37(1):149-165. DOI: 10.1080/0042098002339

[21] Glass R. Introduction: Aspects of Urban Change. Centre for Urban Studies, Report 3 [Internet]. London: Mac Gibbon and Kee; 1964. Available from: http://www.worldcat. org/title/london-aspects-of-change/oclc/1618199\&referer=brief_results/ [Accessed: Sep 25, 2017]

[22] Peri GM. Young workers, learning, and agglomerations. Journal of Urban Economics. 2002;52(3):582-607. DOI: 10.1016/S0094-1190(02)00510-7

[23] Tötzer T, Loibl W. Ansprüche einer alternden Bevölkerung an Wohnen, Wohnumfeld und Mobilität - Zukunftsthemen für die Wiener Stadtpolitik. In: Hanappi-Egger E, Schnedlitz P, editors. Ageing Society, Altern in der Stadt: Aktuelle Trends Und Ihre Bedeutung für Die Stadtentwicklung. Facultas Universitätsverlag Wien. 2009. pp. 606666. ISBN: 978-3-7089-0357-6

[24] Christaller W. Die zentralen Orte in Süddeutschland. Eine ökonomisch-geographische Untersuchung über die Gesetzmäßigkeit der Verbreitung und Entwicklung der Siedlungen mit städtischen Funktionen. 1933. 340 p. Darmstadt: Reprint by Wissenschaftliche Buchgesellschaft. 2009. ISBN-13: 978-3534197361

[25] Christaller W. Central Places in Southern Germany. Translated by Carlisle W. Baskin. Englewood Cliffs, NJ: Prentice-Hall; 1966. ISBN: 978-0131226302

[26] Cox W. Traffic Congestion in the World: 10 Worst and Best Cities [Internet]. 2014. Available from: http://www.newgeography.com/content/004504-traffic-congestion-world10-worst-and-best-cities [Accessed: Sep 25, 2017]

[27] Jacobsen S. More Density Does Not Equal More [car] Traffic [Internet]. 2014. Available from: http://transitized.com/2014/01/14/density-equal-car-traffic/ [Accessed: Sep 25, 2017]

[28] Tosics I, RavetzJ. Managing growth. In:Piorr A, RavetzJ, Tosics I, editors. Peri-urbanisation in Europe [Internet]. Frederiksberg, Copenhagen: Academic Books; 2011. pp. 80-87. Available from: http:/www.openspace.eca.ed.ac.uk/wp-content/uploads/2015/12/Peri_ Urbanisation_in_Europe_printversion.pdf [Accessed: Sep 25, 2017]

[29] Ahrend R, Gamper C, Schumann A. The OECD Metropolitan Governance Survey: A Quantitative Description of Governance Structures in Large Urban Agglomerations, OECD Regional Development Working Papers, 2014/04 [Internet]. Paris: OECD Publishing; Available from: http://www.oecd-ilibrary.org/urban-rural-and-regionaldevelopment/the-oecd-metropolitan-governance-survey_5jz43zldh08p-en [Accessed: Oct 10, 2017]

[30] Brunet R. Les villes europeénnes: Rapport pour la DATAR. Montpellier: RECLUS. 42nd European Congress of the Regional Science Association. Dortmund, Germany. [Internet]. 1989. 20 p. Available from: http://www-sre.wu-wien.ac.at/ersa/ersaconfs/ersa02/cd-rom/ papers/210.pdf [Accessed: Oct 10, 2017] 
[31] Hospers GJ. Beyond he Blue Banana? Structural Change in Europe's Geo-Economy. Dortmund, Germany: 42nd European Congress of the Regional Science Association; 2002. 20pp. Accessible from: http://www-sre.wu-wien.ac.at/ersa/ersaconfs/ersa02/cdrom/papers/210.pdf [Accessed: 2017-10-10]

[32] Suffolk Community College. Urbanization - When, Where and Why Did Urbanization Occur in Europe? [Internet]. 2012. Available from: http://www2.sunysuffolk.edu/westn/ urban.html [Accessed: Oct 10, 2017]

[33] Pevsner N, Bridget C. London I: The Cities of London and Westminster. Rev. edition. London: Penguin; 1973. ISBN-10: 0140710124

[34] Wikipedia. History of London. [Internet]. Available from: https://en.wikipedia.org/wiki/ History_of_London [Accessed: Oct 10, 2017]

[35] Wikipedia. Demography of London. [Internet]. Available from: https://en.wikipedia. org/wiki/Demography_of_London [Accessed: Oct 10, 2017]

[36] Wikipedia. Demographics of Paris. [Internet]. Available from: https://en.wikipedia.org/ wiki/Demographics_of_Paris [Accessed: Oct 10, 2017]

[37] Wikipedia. Rhine-Ruhr. [Internet]. Available from: https://en.wikipedia.org/wiki/ RhineRuhr [Accessed: Oct 10, 2017]

[38] Batty M, Longley P. Fractal Cities: A Geometry of Form and Function. San Diego, CA and London: Academic Press; 1994. ISBN: 978-0124555709

[39] Zach WD, Evers K. Die Berliner Schnellbahnnetze - ihre Entwicklung und Funktionen. In: Monatsschrift 2003 /07. [Internet]. Available from: http://docplayer.org/29591956-Die-berliner-schnellbahnnetze-ihre-entwicklung-und-ihre-funktionen.html [Accessed: Nov 10, 2017]

[40] Cardiff University: The Growth of Gated Communities. Summary from the European FP7 project GATEPLUG. [Internet]. Available from: http://cordis.europa.eu/result/ rcn/148820_en.html [Accessed: Nov 10, 2017]

[41] Adhikar S. 10 Oldest Ancient Civilizations Ever Existed. [Internet]. Available from: https://www.ancienthistorylists.com/ancient-civilizations/10-oldest-ancient-civilizations-ever-existed/ [Accessed: Nov 10, 2017]

[42] Echeverria. A. Urban Change in Iran: Two Millennia of Urban Planning. 2002. [Internet]. Available from: http://thisbigcity.net/urban-change-in-iran-two-millennia-of-urban-planning [Accessed: Nov 10, 2017]

[43] Wikipedia. List of Agglomerations. [Internet]. 2017. Available from: https://en.wikipedia. org/wiki/List_of_agglomerations_by_population [Accessed: Nov 10, 2017]

[44] Ghanbran AH. Iranische Basare im Wandel. [Internet]. 2004. Available from: https://elib. unistuttgart.de/bitstream/11682/44/3/Kap00_Einfuehrung.pdf [Accessed: Nov 11, 2017]

[45] Abdoos M, Norouzi M, The Recognition of Structural-Spatial Development Models in the Immediate Primary Nucleolus Ranges of Iranian Historical Cities and Presenting 
Design Approach, Urban Change in Iran. UK: University College London [Internet]. 2014. Available from: https://www.ucl.ac.uk/bartlett/development/sites/bartlett/files/ proceedings-10-02-2014.pdf [Accessed: Nov 15, 2017]

[46] The Statistics Portal [Internet]. Available from: https://www.statista.com/statistics/455841/ urbanization-in-iran/ [Accessed: Nov 12, 2017]

[47] Zare M, Panagopoulos T, Loures L. Simulating the impacts of future land use change on soil erosion in the Kasilian watershed, Land use Policy. Amsterdam: Elsevier; 2017;67:558-572. ISSN: 0264.8377

[48] Banakar R. Driving Culture in Iran: Law and Society on the Roads of the Islamic Republic. Tehran: L.B.Tauris. Sew edition; 2016. 304 p. ISBN-13: 978-1784534486

[49] Financial Tribune. Iran's Housing, Urbanization Policies, Performance Outlined. [Internet]. 2016. Available from: https://financialtribune.com/articles/economy-business-and-markets/51820/iran-s-housing-urbanization-policies-performance [Accessed: Nov 13, 2017]

[50] Zanjani H, Housing in Iran. [Internet]. 2004. Available from http://www.iranicaonline. org/articles/housing-in-iran [Accessed: Nov 14, 2017]

[51] Arjumandnia A. National Strategy for Housing of Youth. Tehran: National Youth Organization; 1988

[52] Rassoolimanesh SM, Jaafar M. Urban planning and management system in Iran: Review and assessment. Middle-East Journal of Scientific Research. 2013;18(2):220-229. DOI: 10.5829/idosi.mejsr.2013.18.2.12435

[53] Wikipedia: Ancient Chinese Urban Planning. [Internet]. 2017. Available from: https:// en.wikipedia.org/wiki/Ancient_Chinese_urban_planning) [Accessed: Oct 13, 2017]

[54] Wikipedia. Urbanization in China. [Internet]. 2017. Available from: https://en.wikipedia. org/wiki/Urbanization_in_China [Accessed: Nov 13, 2017]

[55] Wikipedia. Beijing City Fortifications. [Internet]. 2017 Available from: https:// en.wikipedia.org/wiki/Beijing_city_fortifications [Accessed: Oct 13, 2017]

[56] The World Bank. Data. [Internet]. Available from: https://data.worldbank.org/indicator/ NY.GDP.PCAP.CD [Accessed: Oct 13, 2017]

[57] Chan KW. The Chinese Hukou system at 50. Eurasian Geography and Economics. 2009;50(2):197-221. DOI: www.tandfonline.com/doi/abs/10.2747/1539-7216.50.2.197

[58] Baculinao E. Jing-Jin-Ji: China Planning Megalopolis the Size of New England [Internet]. 2017. Available from: https://www.nbcnews.com/news/world/jing-jin-ji-china-planningmegalopolis-size-new-england-n734736 [Accessed: Oct 13, 2017]

[59] Shao Y. Current State of China's national new-type urbanization construction and deployment of new reinforcement measures. Mizuo China Monthly. [Internet]. 2014. Available from: https://www.mizuhobank.com/fin_info/cndb/economics/monthly/pdf/ R512-0079-XF-0103.pdf. [Accessed: Oct 13, 2017] 
[60] UN Habitat. The State of Latin American and Caribbean Cities 2016. Towards a New Urban Transition. United Nations Human Settlements Programme. Lanham: Rowman \& Littlefield; 2016. 164 p. ISBN: 987-1-4422-4916-5

[61] Kingstone P. The Political Economy of Latin America. Reflections on Neoliberalism and Development. New York, NY: Routledge; 2011. ISBN-13: 978-0415998277

[62] Inostroza L, Baur R, Csaplovics E. Urban sprawl and fragmentation in Latin America: A dynamic quantification and characterization of spatial patterns. Journal of Environmental Management. 2012;115:87-97. DOI: 10.1016/j.jenvman.2012.11.007

[63] CEPAL. Panorama Social de América Latina. Naciones Unidas: Comisión Económica para América Latina y el Caribe; 2010

[64] Hidalgo R. ¿Se acabó el suelo en la gran ciudad? Las nuevas periferias metropolitanas de la vivienda social en Santiago de Chile. EURE; 2007. XXXIII, pp. 57-75. http://dx.doi. org/10.4067/S0250-71612007000100001

[65] Ortiz J, Morales S. Impacto socioespacial de las migracionesintraurbanas en entidades de centro y de. EURE; 2002. XXVIII, pp. 171-185. https://www.eure.cl/index.php/eure/ article/view/1249/346 [Accessed: 2017-10-10]

[66] Inostroza L. Informal urban development in Latin American urban peripheries. Spatial assessment in Bogotá, Lima and Santiago de Chile. Landscape and Urban Planning. 2016;165:267-279. DOI: 10.1016/j.landurbplan.2016.03.021

[67] Borsdorf A, Hidadgo R, Sanchez R. A new model of urban development in Latin America: The gated communities and fenced cities in the metropolitan areas of Santiago de Chile and Valparaíso. Cities. 2007;24(5):365-378. DOI: 10.1016/j.cities.2007.04.002

[68] Coy M. Gated communities and urban fragmentation in Latin America: The Brazilian experience. Geojournal. 2006;66:121-132 03432521

[69] Janoschka M. El nuevo modelo de la ciudad latinoamericana: fragmentación y privatización. 2002. EURE, XXVIII. n85

[70] Kanitscheider S. Condominios und fraccionamientos cerrados in Mexiko-Stadt. Sozialräumliche Segregation am Beispiel abgesperrter Wohnviertel. Geographica Helvetica. 2002;57(4):253-263 ISSN: 0016-7312

[71] Caldeira TPR. City of Walls, Crime, Segregation, and Citizenship in São Paulo. Berkeley, Los Angeles, CA: University of California Press; 2000. ISBN: 9780520221437

[72] UN Habitat. The State of Latin American and Caribbean Cities 2012. Towards a New Urban Transition. United Nations Human Settlements Programme. Nairobi: Earthscan publications; 2012. 160 p. ISBN: 978-92-1-132468-6

[73] UN Habitat. State of the World's Cities 2010/2011 - Cities for All: Bridging the Urban Divide. United Nations Human Settlements Programme. Nairobi: Earthscan publications; 2011. 220 p. ISBN: 978-1-84971-175-3 
[74] LSE Cities. Cities and Social Equity: Inequality, Territory and Urban Form. Detailed Report. Urban Age Programme. [Internet]. 2009. Available from: http://eprints.lse. ac.uk/26754/ [Accessed: Oct 16, 2017]

[75] LSE Cities. Cities Health and Well-being. Urban Age Programme. [Internet]. 2011. Available from: https://secities.net/objects/research-projects/cities-health-and-well-being [Accessed: Oct 16, 2017]

[76] Hidalgo R, Borsdorf A. El crecimiento urbano en Europa: conceptos, tendencias y marco comparativo para el área metropolitana de Santiago de Chile. Estudios Geográficos. 2009;LXX(266):181-203. ISSN: 0014-1496

[77] Germani G. Estructura Social de Los Argentinos. Raigal: Buenos Aires; 1955

[78] Germani G. Política y sociedad en una época de transición: de la sociedad tradicional a la sociedad de masa. Buenos Aires: Editorial Paidos; 1968

[79] UNDP Human Development Report 2016. Human Development for Everyone. United Nations Development Programme. New York: United Nations; 2016. ISBN: 978-92-1-126413-5

[80] Roy A. Urban Informality, towards an epistemology of planning. In: Journal of American Planning Association. 2005;71(2):147-158. DOI: https://doi/abs/10.1080/01944360508976689 [Accessed: 2017-10-08]

[81] Roy A. Slumdog cities: Rethinking subaltern urbanism. International Journal of Urban and Regional Research. 2011;35(2):223-238. DOI: http://onlinelibrary.wiley.com/doi/ 10.1111/j.1468-2427.2011.01051.x

[82] Sen A. Development as Freedom. New York: Anchor Books Edition; 1999

[83] Gallagher D. The Heavy Price of Santiago's Privatised Water. The Guardian, Sustainable Business, Water. [Internet], 2016. Available from: https://www.theguardian.com/sustainable-business/2016/sep/15/chile-santiago-water-supply-drought-climate-change-privatisation-neoliberalism-human-right [Accessed: Sep 20, 2017]

[84] America2050.org. Megaregions. [Internet]. 2017. Available from: http://www.america2050.org/content/megaregions.html [Accessed: Sep 30, 2017]

[85] The Guardian. Cities in Numbers: How Patterns of Urban Growth Change the World [Internet]. 2015. Available from: https://www.theguardian.com/cities/2015/nov/23/citiesin-numbers-how-patterns-of-urban-growth-change-the-world [Accessed: Sep 30, 2017]

[86] Turner MA, Fortuny K. Residential Segregation and Low-Income Working Families. [Internet]. 2016. Available from: https://www.urban.org/research/publication/residential-segregation-and-low-income-working-families [Accessed: Oct 5, 2017]

[87] Lieb E. How Segregated Schools Built Segregated Cities. [Internet]. 2017. Available from: https://www.citylab.com/equity/2017/02/how-segregated-schools-built-segregated-cities/515373/ [Accessed: Oct 5, 2017] 
[88] Vigdor JL, Glaeser E. The End of the Segregated Century: Racial Separation in America's Neighborhoods, 1890-2010 [Internet]. 2012. Available from: https://www.manhattan-institute.org/html/end-segregated-century-racial-separation-americas-neighborhoods-1890-2010-5848.html [Accessed: Oct 5, 2017]

[89] Moos M. From gentrification to youthification? The increasing importance of young age in delineating high-density living. Urban Studies. 2016;53(14):2903-2920. DOI: https:// doi.org/10.1177/0042098015603292 
